\title{
Klímaváltozás a tőkepiacokon: aktívan kezelt zöldkötvény-alapok vizsgálata*
}

\author{
Németh-Durkó Emilia - Hegedüs Anita
}

Jelen tanulmányban egy nyilvános adatbázisokból elérhető zöldkötvény-portfólió teljesítményelemzését végeztük el a 2017 és 2020 közötti időszakra. Kutatásunk célja a zöld prémium létezésének empirikus bizonyitása volt, melyet kockázattal korrigált mutatószámokkal, azaz a Sharpe-rátával, az $M^{2}$-mutatóval és a Sortino-rátával igazoltunk. A zöld prémium az a hozamkülönbség, amely a zöld- és a konvencionális pénzügyi eszközök között mérhetö. Szakirodalmak szerint a befektetök hajlandóak lemondani 1-9 bázispontú hozamról a klímacélok finanszírozásának érdekében, hogy a kibocsátó a zöldkötvények minősitésével és a jelentési kötelezettséggel járó extraköltségeit fedezzék. Eredményeink megerösitették, hogy a zöldkötvény-portfólió átlagosan 2 bázispontú zöld prémiummal teljesíti alul a benchmark-indexeket. Mindössze egyetlen olyan zöldkötvény-alapot találtunk, amelyikben nincsen zöld prémium, és képes kockázattal korrigált többlethozam elérésére. Megjegyezzük ugyanakkor, hogy a zöldkötvények átlagos teljesítménye a vizsgált időszakban évröl évre javult az alkalmazott mutatók mindegyike szerint.

Journal of Economic Literature (JEL) kódok: C5, G10, G31, G38, Q50

Kulcsszavak: fenntartható befektetések, klímafinanszírozás, zöldkötvények, portfólióelemzés

\section{Bevezetés}

2021 tavaszán Magyarországon debütált a világ leghosszabb futamidejű zöldállampapírja. Óriási befektetői érdeklődés övezte az aukciót, a zöldkötvény tervezett értékesítendő mennyiségét többszörösen felülmúlta a kereslet. A fix kamatozású, 30 éves futamidejú államkötvény, melynek célközönsége a fenntartható befektetések

\footnotetext{
* A jelen kiadványban megjelenő írások a szerzők nézeteit tartalmazzák, ami nem feltétlenül egyezik a Magyar Nemzeti Bank hivatalos álláspontjával.

Németh-Durkó Emilia tanársegéd a Budapesti Corvinus Egyetemen. E-mail: emilia.durko@uni-corvinus.hu Hegedüs Anita MKE-diplomadijas hallgató, pénzügy-számvitel alapszakos hallgató a Budapesti Corvinus Egyetemen. E-mail: hegedus.anita96@gmail.com

Németh-Durkó Emilia részére a tanulmány alapjául szolgáló kutatást az Innovációs és Technológiai Minisztérium által meghirdetett Tématerületi Kiválósági Program 2020 - Intézményi Kiválóság Alprogram támogatta, a Budapesti Corvinus Egyetem „Pénzügyi és Lakossági Szolgáltatások” című tématerületi programja (TKP2020-IKA-02) keretében.
}

A magyar nyelvű kézirat első változata 2021. június 22-én érkezett szerkesztőségünkbe.

DOI: http://doi.org/10.25201/HSZ.20.4.3864 
iránti érdeklődésű alapkezelők, a Bloomberg szerint példátlan a zöld tőkepiacokon. A forintban denominált zöldkötvényeket a tervezetthez képest másfélszer akkora öszszegben bocsátották ki ${ }^{1}$. A környezetvédelmi és fenntartható klímacélok forrásszerzésében hazánk nemcsak az államkötvények piacán, hanem több, Magyarországon múködő vállalat zöldkötvényével van jelen, és a potenciális intézményi befektetők közül sokan a zöld befektetési kínálat további bővítését tervezik².

A zöldkötvények rohamos térhódítása és a fenntartható befektetések iránti egyre növekvő érdeklődés nem hazai sajátosság. Az elmúlt években a globális felmelegedés problémájának kérdésköre egyre fontosabb szerepet játszik a vállalati felelősségvállalásban és a banki klímakockázatok kezelésében. Ahhoz, hogy a gazdasági növekedés és fejlődés fenntartható legyen, olyan fiskális és strukturális reformokra van szükség, amelyek a légkört sújtó károsanyag-kibocsátást visszaszorítják. Az OECD (2017) becslése szerint az elkövetkező 15 évben évente közel 6,9 billió USD-t emésztenek fel a globális felmelegedés lassítását célzó infrastrukturális fejlesztések. A kormányok erőforrása, főleg a fejlődő országokban, nem elegendő a klímaprobléma kezelésére (Reichelt 2010). A hosszú távú, megújulóenergia-alapú megoldások terjedését segítő, és az alacsony szén-dioxid-kibocsátást támogató projektek finanszírozása a bankok számára (Boros 2020), míg a dekarbonizációs folyamatok elősegítése a vállalkozások számára is kihívás (Fogarassy et al. 2018).

A klímaváltozás mérséklésére és a globális felmelegedési károk enyhítésére vonatkozó finanszírozásnak egyik lehetséges módja a zöld portfóliók tőkepiaci elterjedése. Vannak olyan befektetők, akik hajlandóak lemondani a hozam egy részéről a környezeti célok javára, és egyfajta „zöld” prémiumot (greeniumot) fizetni ezért (Zerbib et al. 2019; Baker et al. 2018; Ehlers - Packer 2017). A zöldkötvények azonban nemcsak a környezetvédelem iránti elköteleződött befektetők számára mutathatnak alternatívát, hanem számos előnnyel is bírnak a tőkepiacokon a konvencionális kötvényportfóliókhoz képest. Egyes tanulmányok szerint a zöldkötvény-portfóliók hozama felülmúlja a konvencionális kötvényekét (Karpf-Mandell 2018), sőt, nehéz gazdasági körülmények között, mint például az elmúlt egy év Covid19-időszakában, válságálló befektetéseknek bizonyultak (Taghizadeh-Hesary et al. 2021).

Tanulmányunkban a zöldkötvények fogalmi rendszerét és piacát mutatjuk be egy portfólióelemzésre fókuszálva. A piac sajátosságainak ismertetése mellett a szabályozási problémákra és a szektor nehézségeire is rávilágítunk, például a greenwashing (zöldre mosás) vállalatokat fenntarthatóbbnak feltüntető jelenségről. Empirikus kutatásunkban egy nyilvános adatbázisú portfólióban az aktívan kezelt

${ }^{1}$ Az ÁKK Zrt. 30 éves Zöld Magyar Államkötvényt bocsátott ki a Föld napján. Sajtóközlemény, Államadósság Kezelő Központ. https://akk.hu/download?path=b4246240-e73a-4569-bcfb-c16a33fa5971.pdf. Letöltés ideje: 2021. május 20.

${ }^{2}$ A kulisszák mögött: így zajlik a vállalatoknál a zöld kötvények kibocsátása. https://www.hugbc.hu/hirek/ a-kulisszak-mogott-igy-zajlik-a-vallalatoknal-a-zold-kotvenyek-kibocsatasa/4262. Letöltés ideje: 2021. szeptember 20 . 
zöldkötvény-alapok pénzügyi teljesítményét vizsgáljuk. Kutatási kérdésünk, hogy létezik-e a zöld prémium, azaz a zöldkötvény-alapok hozama szignifikánsan alacsonyabban alakulnak-e a konvencionális kötvényportfólió hozamához képest. Kutatásunk hozzájárul az egyre nagyobb érdeklődést övező, zöld befektetések szakirodalmának bővítéséhez, és a zöldkötvény-alapok pénzügyi teljesítményének vizsgálata a hazai empirikus elemzésekben azok csekély száma és fókusza, a kötvénypiac miatt hiánypótló.

Jelen tanulmány felépítése a következő: A második fejezetben bemutatjuk a zöldkötvények piacát és a kötvénykibocsátások földrajzi és egyéb jellemzőit. A harmadik fejezet az intézményi feltételeket és a szabályozási kereteket ismerteti, míg a negyedik fejezetben empirikus kutatások eredményeire térünk át a zöld prémium létezését vizsgáló tanulmányokkal. Az ötödik fejezetben a saját kutatásunk olvasható, a hatodik fejezet pedig a konklúziókat foglalja össze.

\section{Zöldkötvények a tőkepiacokon}

Míg a fenntartható befektetés fogalma régebb óta ismert a részvénypiacon ${ }^{3}$, a zöldkötvény koncepciója viszonylag új elem. Ebben a fejezetben a zöldkötvények kibocsátásáról és piaci szerepéről írunk, majd a szabályozási problémákat gyűjtjük össze.

\subsection{A zöldkötvények piaci elterjedése}

A legalapvetőbb különbség a zöldkötvények és a konvencionális kötvények között, hogy a zöldkötvényekből származó bevételt környezetbarát projektek finanszírozására fordítják (Pham 2016). A zöldkötvény-befektetési alapok és befektetési jegyek (ETF-ek) összesített nettó eszközértéke dinamikusan növekszik. A klímatudatosságra vonatkozó kötvény 2007-es megjelenése óta a zöldkötvények globális piaca gyorsan bővült, 2018-ban pedig a címkézett zöldkötvények globális kibocsátása elérte a 167 milliárd USD-t, noha a globális kötvénypiacnak napjainkban is csak néhány százalékát teszi ki (Hyun et al. 2019). A bővülés eltérően érintette a tőkepiacokat, a zöldkötvények földrajzilag és a kibocsátó szempontjából is folyamatosan változó szegmenst jelentenek.

Az első zöldkötvényt a szupranacionális Európai Beruházási Bank bocsátotta ki mintegy 600 millió euro értékben, úgynevezett „climate awareness” kötvény néven. Az állami szektorban lévők közül először a norvég Kommunalbanken lépett be a piacra 2010-ben, míg az első szuverén kibocsátó Lengyelország volt, de csak 2016-ban (Filkova et al. 2018). Míg a kibocsátás volumene és értéke minden évben növekedett, az 1. ábra azt mutatja, hogy egyúttal majdnem minden régióban élénkült

\footnotetext{
${ }^{3}$ Fenntartható befektetés alatt a környezeti, társadalmi és vállalatirányítási (environmental, social and governance, ESG) faktorok tőkepiaci megjelenését értjük. Jelen kutatás a zöldkötvények piacának bemutatására korlátozódik.
} 
a zöldkötvény-piac. Az élen végig Európa állt, és a 2018-2019-es fellendülésnek is ez volt a fő területe 79 százalékos növekedéssel, elérve a 117 milliárd USD értékű piacot, így az európai kibocsátások adják a teljes piac felét (CBI 2020). Jókuthy (2020) kiemeli, hogy a piac dinamikáját jól szemlélteti a globális zöldkötvény-kibocsátás elmúlt évekre összpontosuló időbeli koncentrációja. Ma már az egyébként kevésbé fenntartható szempontokat szem előtt tartott, vagy egyenesen egzotikus országok

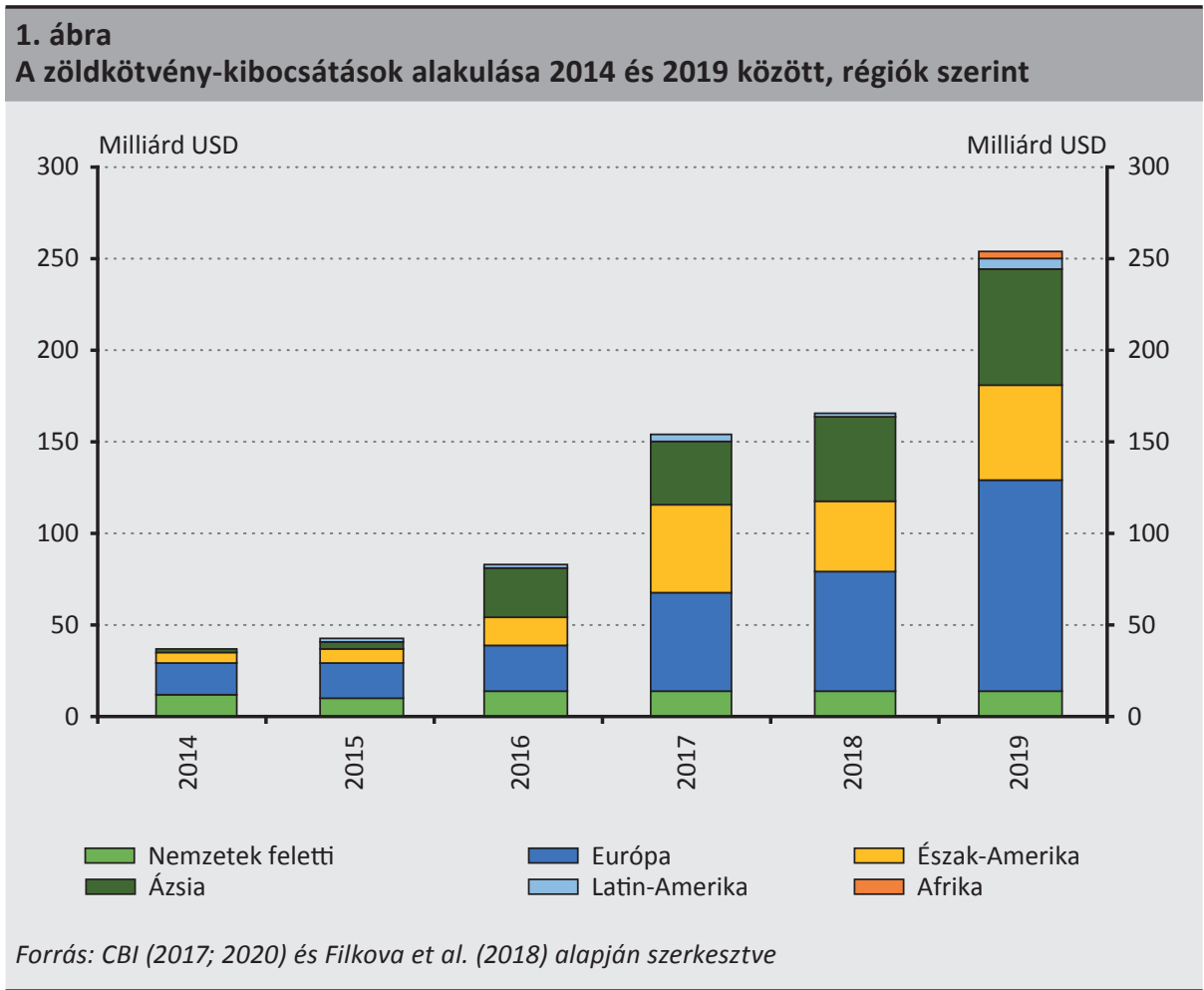

is megjelentek a kibocsátók között, mint például Oroszország, Ukrajna vagy Kenya.

A zöldkötvények biztosította pénzügyi források felhasználása széles körű a zöld célokon belül, hiszen a klímaváltozás megelőzésére és következményeinek enyhítésére, úgynevezett mitigációs célokra egyaránt fordíthatók. A legjellemzőbb beruházási célok között szerepelnek a zöld energetikai fejlesztések, de a víz- és szennyvízgazdálkodás, a közlekedés és az energiahatékonyság javítása is népszerű a finanszírozási célok között. A források közel felét zöld energetikai fejlesztésekre költik (47 százalék), az épületek zöldítésével (22 százalék) együtt a források felhasználásának kétharmadát teszi ki ez a két prioritás. Az energiahatékonyság javítására (8 százalék) és a közlekedés fejlesztésére ( 9 százalék) költenek zöld forrásokból a legkevesebbet (ICMA 2019; MNB 2019). 
Gyors terjeszkedése ellenére a zöldkötvény-piac még mindig nagyon kicsi a globális kötvénypiachoz képest, a globális kötvénykibocsátás körülbelül 2 százalékát teszi ki (Ehlers - Packer 2017). A piac fejlődését korlátozó fő akadály vélhetően a zöldkötvények elfogadott meghatározásának és az általánosan elismert szabványoknak az egyetemes hiánya. Az etikus befektetők a zöldkötvényekbe történő beruházásokat pozitív környezeti hatásokkal társítják, azonban az általánosan ismert zöldkötvény-standardok nélkül a befektetők nehezen azonosítják, hogy a zöldkötvények valóban zöldek-e. Ez eredhet abból, hogy a forrásfelhasználás célját kevésbé konkretizálják a zöldkötvény általános definiálásakor, ugyanakkor pontosan definiálni és dokumentálni kellene a zöld célú forrásfelhasználást és a kiszolgáló folyamatokat is (MNB 2019).

\subsection{Standardok és szabályozási problémák}

A szakirodalom egységesen alkalmazza a zöldkötvények lehatárolásának definícióját. A zöldkötvényekből származó bevétel csak környezetbarát projektek finanszírozására fordítható (Pham 2016), illetve csak olyan beruházásokra, amelyeknek van valamilyen közvetlen vagy közvetett környezet- vagy éghajlatvédelmi előnye (Mihálovits - Tapaszti 2018). Más megfogalmazás szerint olyan hibrid pénzügyi eszköz, amely ötvözi a környezeti előnyöket és a hagyományos fix kamatozású eszközök tulajdonságait, hogy pénzeszközöket irányítson környezetbarát projektekhez (Hyun et al. 2019). Az MNB (2019) összefoglalójában a kibocsátó szerepét hangsúlyozza, akinek felelősségteljesen vállalnia kell, hogy „a kötvénnyel gyűjtött forrásból valamilyen környezetvédelmi vagy ahhoz kapcsolódó beruházást finanszíroz".

Míg a definíció hasonló elemekre épít, addig a szabályozási rendszer, a szerepvállalások és a finanszírozási források felhasználhatóságában már kevésbé nagy az átláthatóság és az összhang. A szakirodalmak (IBA 2021; Mihálovits - Tapaszti 2018; Kolozsi 2019) egyöntetűen hiányolják az egységes szabályozói és minősítői standardokat. Számos zöldkötvény-kibocsátó dolgozott ki saját zöldkötvény-keretrendszert. A fejlesztési bankok, például az Ázsiai Fejlesztési Bank és az International Finance Corporation, valamint más szereplők, például a Nordic Investment Bank is deklarált piacszabályozó mechanizmusokat (Deschryver - de Mariz 2020), de még mindig sok a megválaszolatlan kérdés napjainkban, a friss szakirodalom szerint is.

Az állami vagy magánszervek által támogatott kezdeményezések ebben a szektorban pusztán „ajánlásokat” és „irányelveket” hoztak létre, amelyeket önkéntes alapon lehet elfogadni. A Nemzetközi Tőkepiaci Szövetség (ICMA) által kidolgozott zöldkötvény-alapelvek (GBP) a zöldkötvények kibocsátásával kapcsolatos legfontosabb önkéntes irányelvek (IBA 2021). Az Európai Unió a zöld finanszírozás keretrendszerének kialakításának folyamatában van jelenleg. Az első lépést 2018 márciusában tették meg, amikor az Európai Bizottság átfogó tervet fogadott el a fenntartható finanszírozás előmozdítására (a fenntartható finanszírozásra vonatkozó cselekvési 
terv), és létrehozta a Fenntartható Pénzügyi Műszaki Szakértői Csoportot, amely az EU zöldkötvény-standardjának első tervezetét készítette.

Miután a zöldkötvény olyan eszköz, amelynek célja eliminálni a gazdasági aktivitás környezetet érő negatív hatásait, amitől akár extra hozamot is remélhetnek a befektetők, a zöldkötvények világszerte nagyon hamar jelentős figyelmet kaptak. Mihálovits - Tapaszti (2018) a zöldkötvény-piac kihívásait gyűjtötte össze, és megoldási lehetőségeket is kínált a felsorolt problémákra (2. ábra). A folyamatosan növekvő érdeklődést és tőkepiaci szerepet kevésbé sikeresen követi a szabályozási rendszer, a befektetőket és a kibocsátókat is szolgáló, egységes szabályozási keretek és a piaci transzparencia mind-mind hiányt szenvednek a zöldkötvények kibocsátása kapcsán. Az egységes nemzetközi standardok és a felelősségi körök tisztázása a zöldkötvény minősítése körüli bizonytalanságokat megoldanák, de legalább ilyen hangsúlyosnak kell lennie egy kvantitatív skálázási rendszer kialakításának, amellyel a finanszírozási eredményekről a befektetők visszacsatolást kaphatnak.

\section{2. ábra}

A zöldkötvénypiac kihívásai és megoldásai javaslatai
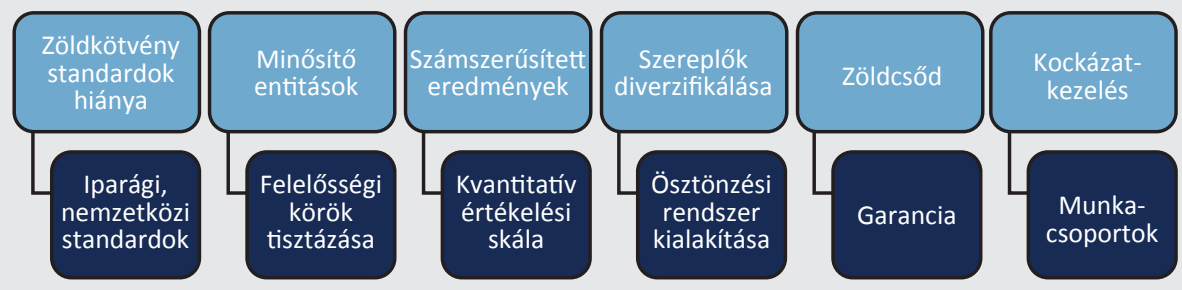

Forrás: Mihálovits - Tapaszti (2018) alapján szerkesztve

Az egzakt szabályozás egységességén kívül kritizálható a nehezen definiált, a finanszírozás célját adó zöld kritérium. Mitől lesz zöld egy beruházás? Ha az energiahatékonyságot egy szénerőmúben javítjuk, fenntartható elveket támogatunk? A klímacélokat nem szolgáló, hanem a klímaváltozás következményeit elszenvedő területek támogathatók? Ilyen, és ehhez hasonló kérdések feltevésével mutat rá Gyura (2019) arra, hogy a „zöldkötvények piacán a bizalom fenntartásához a környezeti hasznosság valamilyen fokú definiálására van szükség”. Amennyiben ez nem történik meg, ellenkező hatást válthat ki a fenntartható értékek képviseltetése a tőkepiacokon.

A vállalatok a rugalmasan értelmezhető szabályozási keret miatt hajlamossá válhatnak saját magukat „zöldebbnek” feltüntetni az általuk valójában birtokolt zöld előnyökhöz képest. Miután az ilyen vállalatok környezeti hasznossága több kutatás szerint is megkérdőjelezhető (Kidd 2015; Shislov et. al. 2016; Gyura 2019), a greenwashing, másnéven a „zöldre mosás” a befektetői bizalom rombolásával a zöld 
címkés pénzügyi eszközök felfutó ágának hamar a végét jelentheti. Timár (2021) szerint a greenwashing jelenség lehet az oka annak, hogy a felelős, fenntartható befektetések árazásában nem talált szignifikáns abnormális hozamokat a New York-i tőzsdén jegyzett cégeknél.

A zöldkötvény-piac, mint láthattuk, jelenleg is sok bizonytalansággal és kihívással küzd a szabályozások oldaláról. Jelen tanulmányban nem térünk ki a klímakockázatokra és a bankok szerepére, de Baranyai - Banai (2020) írásából kiderül, hogy a bankszektor is érintett a klímakockázat kezelésében. Az egységes elvek kialakítása és felülvizsgálatának rendezése a legsürgetőbb kérdések egyike, és miután a dekarbonizáció és a karbonsemleges gazdaságra való áttérés miatt a tőke újraallokálására van szükség (Kolozsi 2019; Fogarassy et al. 2018), a kockázatkezelést át kell alakítani, a fenntarthatóságnak pedig a beruházási döntések szerves részévé kell válnia. Másrészt, a zöldkötvényeknek a kibocsátó klímastratégiájával összhangban kell lennie, tehát elkerülhetetlen a kibocsátó elköteleződésének a vizsgálata a greenwashing visszafogása miatt ${ }^{4}$.

\section{A zöldkötvények árazási sajátosságai - a zöld prémium}

A fenntartható befektetések napjaink felfelé ívelő tudományos kutatásainak egyik területe, évről évre óriási ütemben bővül a szakirodalmi bázis (Németh-Durkó 2019). Dinamikusan növekszik a vállalati, társadalmi és környezeti szempontok banki és tőkepiaci szerepének a hangsúlyozása és mérése. A hozamok, a zöld prémium és legalább akkora érdeklődéssel a fenntartható befektetések kockázatainak számolása is a területek közé tartozik. Ebben a fejezetben a zöldkötvények árazási mechanizmusában megjelenő sajátosságokat ismertetjük, a zöld prémium vizsgálatakor a szakirodalmak által mért hozamkülönbségek bemutatásával.

A zöldkötvényt kibocsátók számára annak igazolása, hogy kötvényeik megfelelnek az adott irányelveknek, a bevételeket külön számlákon tartják, meghatározzák a támogatható projektek kiválasztásához szükséges belső folyamatokat és a bevételek felhasználásáról és hatásáról rendszeresen jelentenek, a zöldkötvény-kibocsátást megdrágíthatja, ezáltal a hagyományos kötvényekhez képest magasabb áron, alacsonyabb hozammal jelennek meg a piacon. Az ennek a mechanizmusnak a következtében kialakuló hozamkülönbséget nevezzük zöld prémiumnak. A zöldkötvény-kibocsátás költségei 0,3 és 0,6 bázispont között mozognak egy 500 millió USD kibocsátásnál (Hachenberg - Schiereck 2018), és különösen nagy kihívást jelentenek a kisebb kibocsátók számára (Forsbacka - Vulturius 2019; Tuhkanen - Vulturius 2020; Sartzetakis 2020).

\footnotetext{
${ }^{4}$ Tapaszti Attila: ESG- és zöldbefektetések a jegybanki portfóliómenedzsmentben. https://economaniablog. hu/2021/04/09/esg-es-zoldbefektetesek-a-jegybanki-portfoliomenedzsmentben/. Letöltés ideje: 2021. június 10.
} 
A zöld prémium vizsgálatának szakirodalmi bázisa meglehetősen kevés számú empirikus munkát tömörít. MacAskill et al. (2021) a zöldkötvények pénzügyi teljesítményének és a zöld prémiumnak az összefoglalójában mindössze 15 tanulmányról számol be a 2007 és 2019 közötti, elsődleges és a másodlagos piacok kötvénykibocsátásairól. A zöld prémium létezésével kapcsolatos konszenzust kutatásuk megerősíti a zöldkötvények több mint felénél, főleg azokra a zöldkötvényekre, amelyek állami kibocsátásúak, és követik a zöldkötvényektől elvárható standardokat és beszámolási, jelentési kötelezettségeket. A zöld prémium nagysága szerinte átlagosan 1-9 bázispont közé tehető, azaz a befektetők átlagosan ekkora hozamról hajlandóak lemondani a környezeti célok finanszírozásának javára. Más szavakkal, a befektetők (negatív) árprémiumot fizetnek a zöldkötvényekért, ami azt jelenti, hogy tolerálják a zöldkötvénynek a hagyományos kötvényhez képest alacsonyabb hozamát. Tuhkanen és Vulturius (2020) úgy fogalmaz, hogy a zöld prémium a kibocsátók javát szolgálja, és enyhíti a kibocsátással járó pénzügyi költségeiket.

A zöldkötvények prémiuma az elsődleges és a másodlagos piacon egyaránt megjelenhet. Az elsődleges piacon, ahol új kötvénykibocsátásokat kínálnak a piacnak, ezeket a kibocsátási költségeket egy zöldkötvénynél magasabb ár képviselné, mint a konvencionális kötvénynél. A másodlagos piacon, miután a kötvényeket kibocsátották, szabadon és árfolyammozgásoknak kitetten kereskednek. A negatív zöld prémium jelenléte az elsődleges vagy a másodlagos piacokon azt jelenti, hogy egy zöldkötvény alacsonyabb hozammal (vagy magasabb áron) kereskedik a hasonló jellemzőkkel rendelkező konvencionális kötvénnyel szemben. „A zöldkötvények forgalomba hozatalával a kibocsátók hitelesen jelzik a környezet védelme, fenntartása vagy helyreállítása iránti elkötelezettségüket. A hozzájuk kapcsolódó hasznok miatti befektetői érdeklődés következtében a kibocsátók általában a zöld- (és harmadik fél által hitelesített) kötvényeket prémiummal tudják árazni" (Sági 2020). A befektetők az alacsonyabb hozamú, de zöldkötvény vásárlásával a kibocsátó számára a környezetvédelmi intézkedéseket megcélzó projektek megvalósítását alacsonyabb finanszírozási költségekkel jutalmazzák.

A szakirodalomból láthatjuk, hogy a zöld prémium létezését a tanulmányok jelentős része empirikusan alátámasztotta (1. táblázat). Különböző időszakokban, más-más piacon, de a konklúzió hasonlóan alakult. A befektetők hajlandók lemondani a hozam egy részéről a zöldkötvények vásárlásával. Más szavakkal, hajlandók felárat fizetni a klímafinanszírozásért. Összefoglalónk alapján a zöld prémiumot legalább -0,17 és legfeljebb -63,2 bázispontban határozták meg a konvencionális kötvények hozamához képest.

Harrison (2019) számol be a munkák között a legkisebb zöld prémiumról. Amerikai és európai zöldkötvények teljesítményében azt találja a 61 db zöldkötvényből álló mintán, hogy a zöldkötvények hozama 0,17 bázisponttal alacsonyabb a konvencionális kötvényekéhez képest. Ennél jóval nagyobb mértékű zöld prémiumot 
(-63,2 bázispont) közöl globális, habár kisebb zöldkötvény-univerzummal rendelkező mintán Nanayakkara - Colombage (2019). Ők a 2016-2017-es időszakra vonatkozóan hasonlították össze a kötvények teljesítményét. Szintén globális piacról összeállított portfóliót elemez Zerbib (2019), akinek az eredeti mintájának végül a tizede kerül bele a modellbe a párosítás módszertanának szigorú kritériumai, illetve azok teljesítése miatt. Minden zöldkötvényhez hasonló tulajdonságú konvencionális kötvényt rendelt, és azt állapította meg, hogy a zöldkötvények hozama 1,8 bázisponttal alacsonyabb a 2013-2017 közötti időszakban. Ez a felár a környezeti célok eléréséért cserébe nem jelentős a szerző szerint, és várhatóan nem veti vissza a befektetők kedvét a zöldkötvényekbe való invesztálástól.

\begin{tabular}{|c|c|c|c|c|c|c|}
\hline \multicolumn{7}{|l|}{ 1. táblázat } \\
\hline Szerző & Évszám & Piac/dimenzió & Módszer* & Időszak & $\begin{array}{l}\text { Zöldkötvények } \\
\text { (db) }\end{array}$ & $\begin{array}{c}\text { Zöld } \\
\text { prémium } \\
\text { (bázispont) }\end{array}$ \\
\hline Ehlers és Packer & 2017 & $\begin{array}{c}\text { USA és } \\
\text { Németország }\end{array}$ & Párosítás & 2007-2014 & 21 & -18 \\
\hline Baker et al. & 2018 & $\begin{array}{c}\text { USA } \\
\text { (önkormányzati) }\end{array}$ & CAPM & 2014-2016 & 2083 & -6 \\
\hline Baker et al. & 2018 & USA (vállalati) & CAPM & 2014-2016 & 19 & - \\
\hline Tang és Zhang & 2018 & globális & OLS & 2007-2017 & 665 & - \\
\hline Hyun et al. & 2018 & globális & Párosítás & 2010-2017 & 60 & - \\
\hline Zerbib et al. & 2019 & globális & Párosítás & $2013-2017$ & 110 & $-1,8$ \\
\hline $\begin{array}{l}\text { Nanayakkara és } \\
\text { Colombage }\end{array}$ & 2019 & globális & OLS & 2016-2017 & 43 & $-63,2$ \\
\hline Harrison & 2019 & EU és USA & OLS & 2019 & 61 & $-0,17$ \\
\hline Gianfrate és Peri & 2019 & EU & Párosítás, OLS & 2013-2017 & 121 & $-0,2$ \\
\hline Karpf és Mandel & 2018 & $\begin{array}{c}\text { USA } \\
\text { (önkormányzati) }\end{array}$ & $\begin{array}{c}\text { Oaxaca-Blinder } \\
\text { dekompozíció }\end{array}$ & 2010-2016 & 1880 & $+7,8$ \\
\hline
\end{tabular}

Megjegyzés: * CAPM - capital asset pricing model, OLS - ordinary least squares.

A zöld prémium létezését kevés kutatás cáfolta meg (Baker et al. 2018; Tang Zhang, 2018; Hyun et al. 2018), miután nem igazolták szignifikáns eltéréssel a zöld és a hagyományos kötvények hozamát. Tang és Zhang (2018) nem talált időben állandó, szignifikáns prémiumot vagy diszkontot a zöldkötvények iránt, ugyanakkor a részvényárfolyamok szignifikáns pozitív reakcióját állapították meg a vállalati zöldkötvény-kibocsátásokra. A részvények likviditásának jelentős javulását hozta a zöldkötvények kibocsátása, ezért egy vállalati döntés a zöldkötvények kibocsátásáról előnyösnek ígérkezik a mindenkori részvényesek számára. Habár Tang - Zhang (2018) munkájával ellentétben Hyun et al. (2018) megjegyzi, hogy 6-9 közötti bázispontú a zöld prémium, de csak a külső minősítésű zöldkötvényeknél, azoknál, amelyeket vagy a CBI (Climate Bonds Initiative) vagy más entitás minősített. A 2010 
és 2017 közötti kutatásuk 60 db, angol fontban denominált zöldkötvényen alapul a hasonló tulajdonságú, hagyományos kötvényekkel szemben, Zerbib (2019) kutatási módszertanának mintájára.

Elemzések tárgya a kibocsátók kategorizálása is, azaz a vállalati és az önkormányzati kibocsátók zöldkötvényei is. Partridge - Medda (2020) jobban teljesítő zöld indexekről számol be. Az önkormányzati zöldkötvények indexe felülmúlta a legközelebbi egyenértékű S\&P indexet 2014 és 2018 között. Karpf - Mandel (2018) kutatásában szintén jobbak voltak a zöldkötvények, a mintegy 2000 elemú adatbázisból a zöldkötvények likviditására kontrollálva, 30 napos időtávon a zöld prémium +7.8 bázispont volt. A prémium ez esetben a kutatások javarészétől eltérően pozitiv érték, tehát az önkormányzatok által kibocsátott zöldkötvények kevésbé tűnnek kockázatosnak a piac és a befektetők számára.

Ami a módszertant illeti, népszerúek a kockázattal korrigált mutatószámok a befektetési alapok teljesítményének elemzésekor, de nemcsak a kötvényeknél, hanem a részvényportfóliókon is számolnak ezzel a megközelítéssel. Chen - Chang (2012) kockázattal korrigált mutatókkal végzett összehasonlító elemzést 131 zöldalapra, melyben a zöldalapok felülteljesítik a konvencionális alapokból álló peer groupot. Fama és French 3 faktoros modelljének kibővített változatának alkalmazásával a hagyományos alapok pénzügyi teljesítménye eredményesebb volt a zöldalapokénál, míg a zöld- és fekete-portfóliók kockázattal korrigált teljesítményei között nem volt szignifikáns különbség. A 175 zöldalap, 259 feketealap, és a 976 konvencionális alap elemzésével Chen - Chang (2012) konklúziójához hasonlóan azt a megállapítást tették, hogy az időablak előretolásával 2012 és 2014 között a zöldalapok egyre magasabb hozamot érnek el, eltünik a zöld prémium (Ibikunle - Steffen 2017).

A szakirodalmi összefoglalónk alátámasztja a zöld prémium empirikus létezését. A kutatások nagy része megegyezik a zöld prémium, vagyis a zöldkötvények negatív hozamának szignifikáns igazolásában. Ettől eltérőt csak nagyon kevés kutatás állít. A következőkben saját kutatásunk eredményeit mutatjuk be.

\section{A zöldkötvény-portfólió és a teljesítménymérésre alkalmazott mód- szerek}

Kutatásunkban egy nyilvánosan elérhető eszközökből álló zöldkötvény-portfóliónak a teljesítményét vizsgáljuk. Empirikus bizonyítékot keresünk a greenium létére azáltal, hogy egy zöld portfólió teljesítménye eléri-e a piaci benchmark-indexek teljesítményét, vagy alulmarad a piachoz képest. Eredményünkből kiderül, hogy jövedelmező befektetési alternatívát kínálnak-e a zöldkötvények, vagy inkább vállalati reputációs célokat szolgálnak, amelyért a fenntarthatóság iránt elkötelezett befektetők fizetni (azaz hozamveszteséget elviselni) is hajlandók. 
Adatbázisunkban aktívan kezelt alapokat gyűjtöttünk össze, melyek célja a viszonyítási alapjuk túlteljesítése. Az aktív befektetési alapkezelés a portfólió-menedzser azon képességére épít, hogy az képes kiválasztani az értékpapírokat és képes megfelelő időzítéssel és egyedi stratégiákkal fellépni a piacon, míg a másik típus, a passzív alapkezelés egy piaci index hozamainak lehető legpontosabb előállításával operál. Egy becslés szerint az aktív alapok 23 százaléka teljesítette túl passzív megfelelőjüket (Stempler 2021), ezért ilyen alapokra esett választásunk.

A zöldkötvény-portfóliók értékeléséhez többféle mutatót alkalmazunk. A piaci viszonyok jellemzésére a CAPM-modellből (itt: az indexmodellből) az alfát és a bétát, a kockázattal korrigált teljesítmény mérésére pedig a Sharpe-rátát, az $\mathrm{M}^{2}$-mutatót és a Sortino-rátát használjuk. Kutatásunk egyik hipotézise, hogy a zöldkötvény-alapok átlagos hozama alacsonyabb, mint a piaci benchmark-hozam, azaz létezik a zöld prémium. A hozamok és a minél valósabb teljesítmény közlése miatt a kockázattal korrigált mutatók értékéből következtetünk a hipotézis megválaszolására. A másik hipotézisünk, hogy van olyan zöldkötvény-alap, amely esetében az aktív alapkezelés értéket teremt, és a piacnál magasabb hozamot ér el az alapkezelő képességének köszönhetően. A hipotézist a zöldkötvények alfáinak eredménye alapján válaszoljuk meg.

\subsection{A vizsgált adatbázis jellemzői}

A viszonylag fiatal piac miatt jelen tanulmányban a zöldkötvények teljesítményének elemzéséhez használt periódus 2017. március 1-től 2020. február 28-ig tart. Az Environmental Finance által definiált 32 zöldkötvény-alapból - mely csak azon alapokat vizsgálta, melyekben a zöldkötvények súlya legalább a felét tették ki - 17 alap felelt meg a hároméves időtáv kritériumának, és ebből is csak 11-nél volt elérhető historikus adat. Az adatbázisunkat Climent - Soriano (2011) kutatásához hasonlóan csak nyílt végű és elsődleges befektetési alapok alkotják, melyek szabadon elérhetők bármely befektető számára. Az eszközosztály fókusza csak és kizárólag a kötvények. Négy különböző adatbázisról töltöttük le az adatokat, melyek a Yahoo Finance, a Boursorama, a Markets és az Umundi voltak. Az elemzésbe bevont zöldkötvény-alapok listáját, pénznemét és nettó eszközértékét a 2. táblázat tartalmazza. 


\section{2. táblázat}

A kutatásban vizsgált zöldkötvény-alapok föbb jellemzői

\begin{tabular}{l|c|c}
\multicolumn{1}{c|}{ Alap neve } & Pénznem & $\begin{array}{c}\text { Nettó eszközérték 2019 } \\
\text { (Millió USD) }\end{array}$ \\
\hline Allianz Green Bond W EUR & Euro & 383,58 \\
\hline Amundi Rspnb Investing Green Bds I C & Euro & 86,79 \\
\hline Amundi Rspnb Investing Imp Gr Bds I C & Euro & 385,17 \\
\hline AXAWF Global Green Bds I Dis EUR & Euro & 251,82 \\
\hline BfS Nachhaltigkeitsfonds Green Bonds & Euro & 21,97 \\
\hline Calvert Green Bond I & USD & 418,39 \\
\hline JSS Sustainable Green Bd Glb P EUR acc & Euro & 24,36 \\
\hline Mirova Global Green Bond N & USD & 39,65 \\
\hline NN (L) Green Bond I Cap EUR & Euro & 1422,64 \\
\hline Raiffeisen-GreenBonds I T & Euro & 103,03 \\
\hline SEB Green Bond D EUR & Euro & 122,62 \\
\hline
\end{tabular}

Forrás: A Yahoo Finance, a Boursorama, a Markets és az Umundi adatbázisok

Az általunk kialakított portfólióban összesen 11 zöldkötvény-alap szerepel. Az alapok által kezelt vagyon összértéke mintegy 4440 millió USD. A zöldkötvény-alapok kumulált nettó eszközértéke kevesebb mint a felét teszik ki az ezen időszak alatti teljes piac által kezelt vagyonnak. A feltüntetett alapok mind nyíltvégűek, pénznemüket tekintve pedig kilenc euro-, kettő pedig USD-árfolyamú. Ugyan az USD pénznemü alapokban az amerikai kötvényeknek a súlya a legnagyobb, az euro pénznemúben pedig az európai kötvényeknek, az elemzés során nem kezeljük őket külön kategóriában, mert mindegyik portfólió területileg is diverzifikált, valamint vállalati és állami kötvényeket is tartalmaznak. A hozamprémium meghatározásához a három hónapos amerikai kincstárjegy hozamát választottuk kockázatmentes hozamnak, melyet a U.S. Department of the Treasury oldaláról töltöttünk le.

Az elemzés fontos részét képezi a megfelelő benchmark-portfóliók kiválasztása, miután az egyes indexek hatása a kötvényalapok hozamára szignifikáns lehet. A kutatásban 3 indexszel dolgoztunk, amelyekhez az alapok teljesítményét hasonlítjuk. Az első index a zöldkötvény-piacot reprezentálja (S\&P Green Bond Index), a másik index (S\&P Global Developed Aggregate Ex-Collateralized Bond Index) a hagyományos kötvénypiacot, a harmadik index ( $\mathrm{MSCl}$ All-Country World Index) a globális értékpapír-piacot. 
A három legnépszerúbb zöld index a Bloomberg Barclays MSCl Green Bond Index, a Solactive Green Bond Index és a S\&P Green Bond Index, melyek közül az utóbbira esett a választásunk, miután az index komponenseinek legmagasabb számával a legdiverzifikáltabb mind közül. Az S\&P Green Bond index célja a globális zöldkötvény-piac nyomon követése. Az úttörő index szigorú szabványokat tart fenn annak érdekében, hogy csak azokat a kötvényeket vonja be, amelyek bevételét környezetbarát projektek finanszírozására használják fel. A globális, fix kamatozású eszközök egyik leggyakrabban használt benchmarkja az S\&P Global Developed Aggregate Ex-Collateralized Bond Index, amely szuverén, kormányzati- és piaci vállalatok által kibocsátott kötvények teljesítményének nyomon követésére szolgál.

A harmadik index, amelyhez a zöldkötvény-alapok teljesítményét mértük, a MSCl All-Country World Index. A legtöbb befektetési alap teljesítményéről szóló szakirodalomban a FTSE All-World Index mellett ezt használják a teljes pénzügyi piac reprezentálására. Az $\mathrm{MSCl}$ All-Country World Index globális részvényindex, melynek célja, hogy a nagy- és közepes kapitalizációjú részvényeket 23 fejlett és 26 feltörekvő piacon reprezentálja. 2019 decemberében több mint 3000 alkotóeleme volt 11 különböző ágazatban.

\subsection{Az aktívan menedzselt portfólióelemzés alkalmazott módszertana}

A szakirodalomban számos szempont szerint értékelik az aktívan menedzselt portfóliók teljesítményét, és leggyakrabban kockázattal korrigált mutatókat, többek között a Jensen-alfát, a Sharpe-rátát és a Sortino-rátát, illetve az $\mathrm{M}^{2}$-mutatót alkalmazzák (Rácz 2019). A zöld prémium számításakor az összefoglalónkban ismertetett szakirodalmak általában egy hagyományos kötvényportfólióval mérik össze a zöld portfólió teljesítményét. Ettől eltérően jelen kutatás három különböző eszközosztályra fókuszáló piaci (benchmark) index (részvényindex, kötvényindex, zöldkötvény-index) teljesítményéhez viszonyítva keres bizonyítékot a zöld prémium létezésére.

A legelterjedtebb mérőszám a kockázattal kiigazított hozamokra és a befektetések összehasonlítására a Sharpe-ráta, amely az egy kockázati, vagyis szórás egységre jutó többlethozamot mutatja meg. Egy befektetés „vonzerejét” jelenti, azt, hogy egységnyi vállalt többletkockázatért megfelelő többlethozamot biztosít-e az adott befektetési alap. Miután a hozamok vizsgálata torz képet adhat egy befektetési stratégiáról az eltérő kockázatvállalás miatt, ezért a kockázattal korrigált mutatókkal a különböző kockázattal rendelkező eszközök összehasonlíthatóvá válnak. A Sharperátát a következő képlet adja meg:

$$
\text { Sharpe-ráta }=\left(r_{i}-r_{f}\right) / \sigma_{i},
$$

ahol $r_{i}$ az eszköz hozama, $r_{f}$ a kockázatmentes hozam és $\sigma_{i}$ az eszköz szórása, azaz kockázata. A Sharpe-rátával az alapok teljesítménye összehasonlítható a referenciaindexekével is. Ha egy alap Sharpe-rátája magasabb, mint az indexeké, az azt jelenti, 
hogy felülteljesítette az indexet. Vannak azonban olyan esetek, amikor a Sharpe-ráta nem ad megbízható eredményt, például a hozamok negatív ferdeségénél alábecsüli a kockázatot, azaz a stratégia valójában kockázatosabb, mint amit a Sharpe-arány mutat $^{5}$, ezért más mutatószámokat is alkalmazunk.

A Sortino-mutató a Sharpe-ráta egyik továbbfejlesztése, amely szintén a kockázattal módosított teljesítményt méri, de a kettő között az a különbség, hogy míg a Sharpe-ráta a teljes szórással számol, a Sortino-ráta csak a negatív szórással, azaz a Sharpe-rátával ellentétben nem bünteti a pozitív irányú volatilitást. Kiszűri a befektetők által egyébként kedvelt esetet, amikor az árfolyam emelkedése miatt nő a volatilitás. A Sortino-mutató képlete a hozamprémium és a portfólió negatív szórásának a hányadosa.

$$
\text { Sortino-ráta }=\left(r_{i}-r_{f}\right) / \sigma_{d},
$$

ahol $r_{i}$ az eszköz hozama, $r_{f}$ a kockázatmentes hozam és $\sigma_{d}$ a negatív hozamok szórása.

A Markowitz-féle portfólióelmélet alapján és az erre épülő tőkepiaci árfolyamok modell (CAPM) továbbfejlesztésével különböző modellek, mutatószámok használhatók a befektetési lehetőségek értékelő összehasonlításra a kockázat és hozam optimalizációjának szempontjából. A CAPM-modell elméletben jól működik, azonban feltevései a gyakorlatban sérülnek, és piaci anomáliák sokaságát hozták magukkal. Miután a gyakorlatban a realizált (ex post) hozamok figyelhetők meg (Lovas et al. 2019), ezért a CAPM-modell helyett az egyfaktoros indexmodellel dolgozunk. Az egyfaktoros indexmodell olyan regressziós modell, amely a portfólió által elért többlethozamot méri a benchmarkhoz képest. Ezzel a megközelítéssel tudjuk mérni az általunk összeállított zöldkötvény-portfólió piachoz viszonyított teljesítményét. Az eszköz- és a piac hozamprémiumaira a legkisebb négyzetek módszerével (OLS) illesztett egyenes az értékpapír karakterisztikus egyenese $(\mathrm{SCL})$, melynek meredeksége béta, metszéspontja alfa (Bodie et al. 2005). Az alfa vagy más néven Jensen-alfa a portfólió többlethozamát számszerűsíti, kifejezi, hogy mekkora a különbség a portfólió átlagos hozama és a CAPM szerinti (itt: indexmodell szerinti) hozam között.

$$
\alpha_{i}=E\left(r_{i}\right)-\left[r_{f}+\beta_{\mathrm{i}} \cdot\left(E\left(r_{m}\right)-r_{f}\right)\right],
$$

ahol $\alpha_{i}$ a többlethozam, $E\left(r_{i}\right)$ a CAPM-modell elméleti várható hozama, $\beta_{i}$ a nem diverzifikálható piaci kockázat és $E\left(r_{m}-r_{f}\right)\left(=E\left(r_{m}\right)-r_{f}\right)$ a várható piaci kockázati prémium. A Jensen-alfa $\left(\alpha_{i}\right)$ pozitív értékéből arra következtethetünk, hogy az alapkezelő a referenciaindexnél magasabb hozamot ért el, tehát az aktív portfóliókezelés eredményes volt. A regressziós egyenletben az alfát t-próbával teszteltük, melyben

\footnotetext{
${ }^{5}$ Rollinger, T.N. - Hoffmann, S.T.: Sortino: A 'Sharper' Ratio. https://www.cmegroup.com/education/files/ rr-sortino-a-sharper-ratio.pdf. Letöltés ideje: 2019. június 5.
} 
$\mathrm{H}_{0}: \alpha=0$. Ha a nullhipotézis elutasítható, azaz $\alpha$ nem egyenlő nullával, akkor az aktív portfóliókezelésnek van hozzáadott értéke. $A \beta_{i}$ a piaci portfólió hozamprémiumával való együttmozgását magyarázza.

A mutatókat először a teljes időszakra, majd évekre lebontva számoljuk ki, hogy a kockázattal korrigált hozamok időbeli alakulását is megfigyeljük. Ibikunle - Steffen (2017) tanulmányából kiindulva arra számítunk, hogy a zöldkötvény-alapoknál is hasonló növekvő trend lesz látható, mint amit a zöldrészvény-alapoknál tapasztalt a fenntartható befektetések térhódítása miatt.

\section{Az zöldkötvény-alapok teljesítményének mérése}

A 11 zöldkötvény-alap és a 3 referenciaindex átlagos éves hozamát és volatilitását mutatjuk be elsőként, hogy áttekintést adjunk a vizsgálatba bevont zöldkötvény-alapok alapvető jellemzőiről. A vizsgált időszakra a napi árfolyamadatokból évesített logaritmikus hozamokat számoltunk, a napi hozamok és a szórás évesítése során az átlagos kereskedési napokkal (250-nel) korrigálva. A hozamprémium meghatározásához a 3 hónapos amerikai kincstárjegy hozamát tekintettük kockázatmentes hozamnak.

\section{3. ábra}

A zöldkötvény-alapok és a referenciaindexek éves átlagos hozamai és szórásai 2017. február 28. és 2020. február 28. között

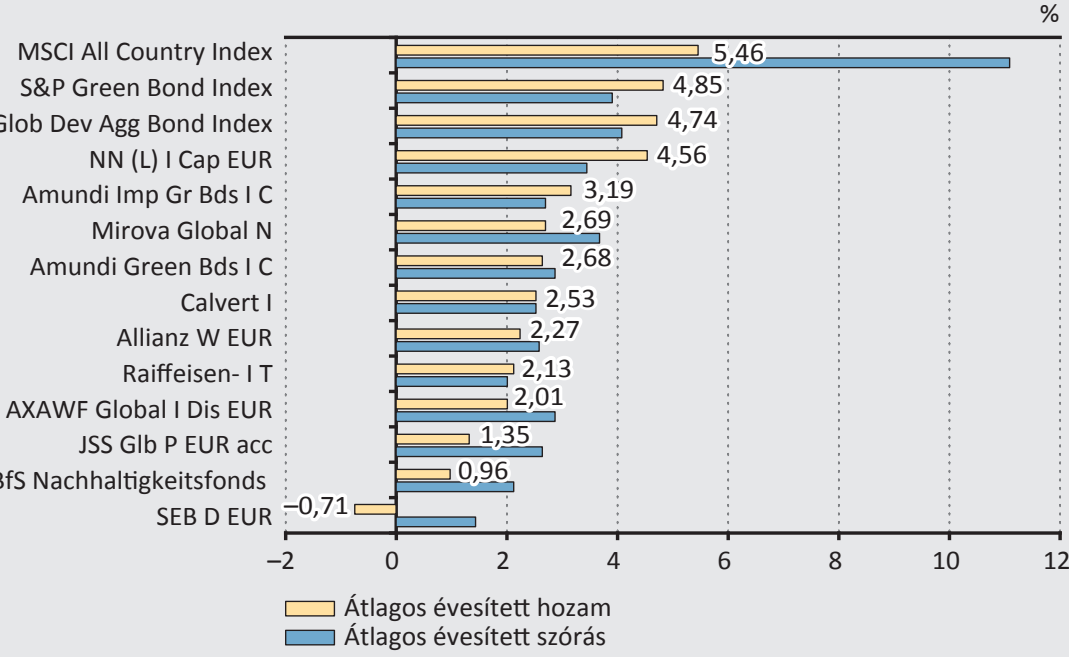

Megjegyzés: Az ábrán értékekkel feltüntetve az évesített hozamok láthatók. 
A 11 zöldkötvény-alap közül tíznek sikerült pozitív hozamot elérnie, azonban a zöldkötény-alapok hozama minden vizsgált benchmark-portfóliónál alacsonyabb hozamot realizált, ezért egyik sem tudta megverni a piacot, egyik benchmark-indexhez képest sem. Az alapok hozama átlagosan 2,15 százalék volt, ezzel csak a kockázatmentes hozamot ( 2 százalék) sikerült felülmúlniuk, de az indexek 4-5 százalék körüli hozamától messze elmaradnak. A zöldkötvény-alapok közül a legnagyobb eszközértékű, az NN (L) alap teljesített a legkiemelkedőbben (4,56 százalék), azonban ezzel az eredménnyel is csak megközelítenie sikerül a legalacsonyabb hozamú referenciaindexet (4,74 százalék). Jellemzően az alacsonyabb hozam mellett a vizs-

gált alapoknak a kockázatuk is alacsonyabb volt. Az eredmények azt mutatják, hogy a zöldkötvény-alapok ugyan nem jövedelmezőbb befektetések, de a piaci portfóliókhoz képest kevésbé kockázatosak (3. ábra). Más kutatás is jutott arra a megállapításra, hogy a fenntartható befektetések alacsonyabb kockázatúak más portfólióknál (Taghizadeh-Hesary et al. 2021).

A szórások alakulását illetően nem meglepően az $\mathrm{MSCl}$ All Country Indexnek a szórása a legmagasabb, ami indokolható azzal, hogy a részvények kockázatosabb eszköznek számítanak, mint a kötvények. Az indexek közül az S\&P Green Bond index, azaz a zöldkötvény-index és az S\&P Bond Index, azaz a hagyományos kötvényportfólió indexének teljesítménye kockázatban és hozamban is közel azonos. Megjegyezzük, hogy a legnagyobb hozamú zöldkötvény-alap csak a második legnagyobb kockázatot viseli, azonban a hozam és szórás kapcsolatáról csak a kockázattal korrigált mutatók számolása után érdemes további következtetéseket levonni.

\subsection{A kockázattal korrigált mutatók}

Az előzőekben bemutatott, évesített hozamok alapján kapott sorrend a zöldkötvények és a benchmarkok között vitatható, miután a portfóliómenedzserek különböző kockázat mellett érték el a hozamokat. A teljesítmények korrekt értékelésére alkalmasabbak a kockázattal korrigált mutatószámok. Jelen tanulmányban a Sharpe-ráta és két továbbfejlesztett változata, a Sortino-ráta és az $\mathrm{M}^{2}$-mutató alapján kapott teljesítményeket ismertetjük.

Míg a hozamok esetén a három benchmark-index teljesített a legjobban, a legmagasabb Sharpe-rátát a zöld benchmark-index és egy zöldkötvény-alap, az NN (L) alap érte el. A részvénypiaci indexet két zöldkötvény-alap kockázattal korrigált mutatója is megelőzte. A zöldkötvény-alapokra számolt Sharpe-ráták három alap kivételével pozitívak, ami azt jelenti, hogy a legtöbb zöldkötvény-alap felülteljesítette a kockázatmentes hozamot. A zöldkötvény-alapok átlagos teljesítménymutatója 0,07, míg a negatív értékek kizárásával 0,36, így összességében éppen csak a részvénypiaci index előtt végeznek (4. ábra). 
Az NN (L) alap volt az egyetlen olyan zöldkötvény-alap, amely a zöld- és a hagyományos piaci indexeknél is nagyobb teljesítményt ért el a vizsgált periódusban. $A$ két Amundi-alap ugyan a két említett index mögött végzett, de a részvényindex felett teljesített. Az alapoknak tehát csak a negyede bizonyult jobb befektetésnek a piacnál és volt képes egységnyi kockázatra vetítve magasabb hozam elérésére. Az eredményekből az is látszik, hogy pusztán a hozam alakulásából nem érdemes a teljesítményre következtetni, mert például a Mirova Global $\mathrm{N}$ alap magasabb hozammal zárta a vizsgált időszakot, mint az Amundi Imp alap (3. ábra), azonban ezért jóval magasabb kockázatot is vállalt, és így az egységnyi kockázatra vetített hozamban az Amundi Imp alap - mint ahogyan ezt a Sharpe-ráta-rangsor is tükrözi - jobb teljesítményt ért el. A legalacsonyabb hozamú zöldalapokról elmondható, hogy a Sharpe-ráta általi sorrendben is utolsók, miután a kockázatmentes hozamot nem sikerült elérniük (4. ábra).

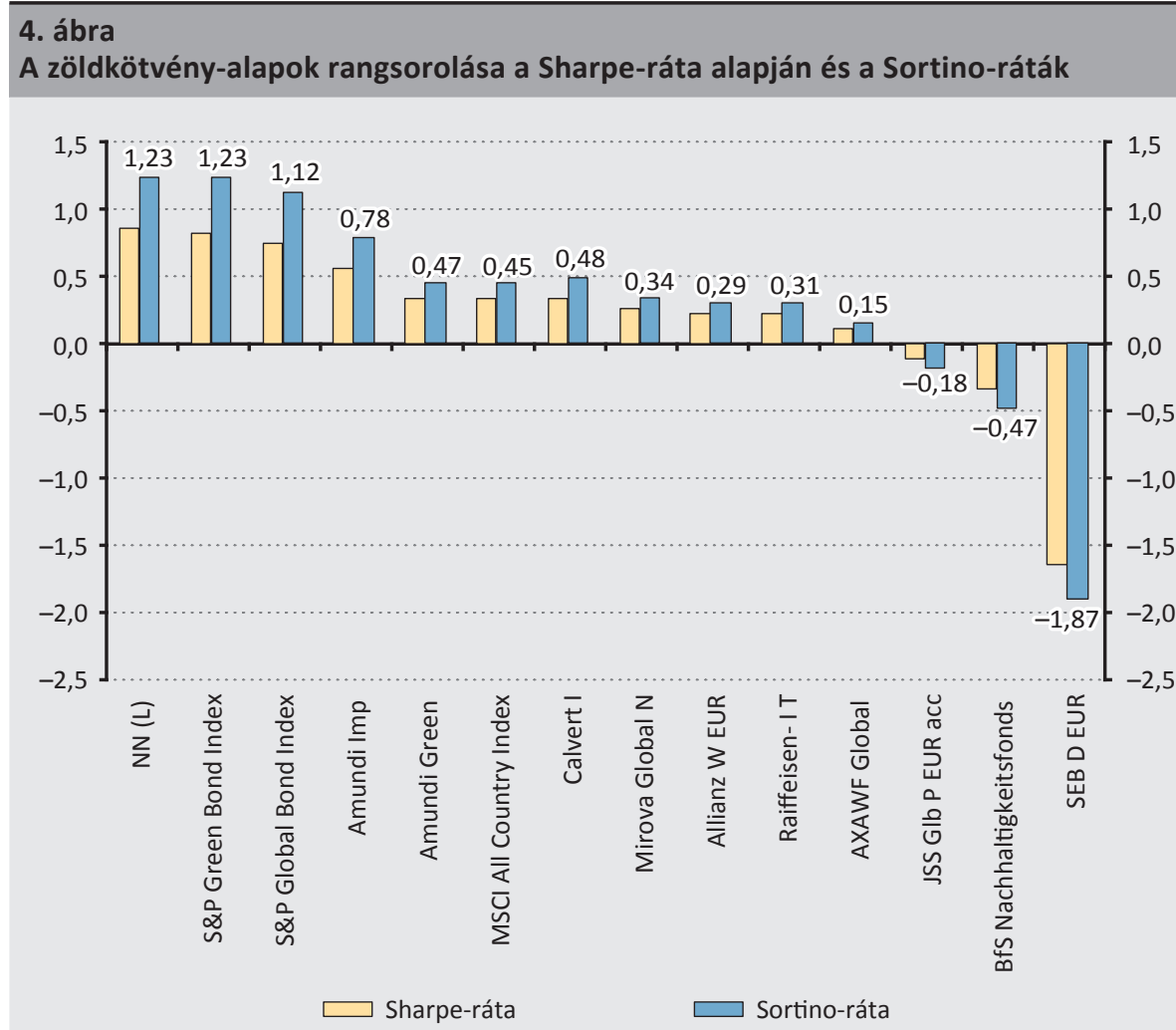

Megjegyzés: Az ábrán értékekkel feltüntetve a Sortino-ráta értékei láthatók. 
A Sortino-ráta a Sharpe-ráta egyik továbbfejlesztett változata, amely kifinomultan kezeli az árfolyamváltozásokat, mert nem bünteti az árfolyamok emelkedését, csak a visszaesésük kockázatával számol. A Sortino-ráta eredményei a Sharpe-ráták sorrendjén csak két alap esetén változtatott. Lényeges, hogy egy újabb alap, a Calvert I alap is megveri a részvénypiaci benchmarkot, így már a 11 zöldkötvény-alapból 4 alap bizonyul jó befektetésnek az aktuális piaci körülmények között (4. ábra). A pozitív Sharpe-rátájú portfóliók Sortino-mutatója mind magasabb, azaz a pozitív irányba kiugró értékek száma több volt, mint a negativoké. Ezért egy kis mértékü balra elnyúló, jobbra ferde hozameloszlást feltételezünk, amit a hozamokra futtatott leíró statisztikai függvény is alátámaszt, ahol a ferdeségi mutató negatív, és az átlagok kisebbek a mediánnál, az pedig a módusznál. Tehát a hozamok aszimmetrikusak, eloszlásuk nem normális. Ezért a Sortino-mutató pontosabb eredményt ad az alapok teljesítményéről.

Külön, éves bontásban tekintve az egyes zöldkötvény-alapok hozamait, növekvő tendencia fedezhető fel teljesítményükben. A megfigyelt hozamváltozás indikálja a kockázattal korrigált hozammutatók vizsgálatát az időszak szerinti bontásban. A vizsgálat első két időszakában az alapok Sortino-mutatói negatívak, azonban a harmadik évben, azaz a 2019. március eleje és 2020. február vége közötti adatok alapján, hét alap mindhárom benchmark-indexet túlteljesítette, a négyből három alap pedig két benchmark-indexnél is jobban teljesített (3. táblázat). A negatív Sortino-rátájú SEB D EUR zöldkötvény kivételével tehát mindegyik zöldalap teljesítménye felülmúlta a referenciaindexeket a vizsgált periódus 3. évében. Eredményünk összhangban áll Chen - Chang (2012) és Ibikunle - Steffen (2017) konklúziójával, miszerint az időablak előretolásával a zöldalapok egyre jobban teljesítenek, és eltűnik a zöld prémium. 


\begin{tabular}{|c|c|c|c|}
\hline \multicolumn{4}{|c|}{$\begin{array}{l}\text { 3. táblázat } \\
\text { A zöld prémium időbeli alakulásának vizsgálata a Sortino-mutató évenkénti bon } \\
\text { tásával }\end{array}$} \\
\hline \multirow[b]{2}{*}{ Zöldkötvény-alapok } & \multicolumn{3}{|c|}{ Időszakok Sortino-mutatói } \\
\hline & $\begin{array}{c}2017.03 .01 .- \\
2018.02 .28 .\end{array}$ & $\begin{array}{c}2018.03 .01 .- \\
2019.02 .28\end{array}$ & $\begin{array}{c}2019.03 .01 .- \\
2020.02 .28 .\end{array}$ \\
\hline Allianz W EUR & $-1,14$ & $-0,98$ & 2,77 \\
\hline Amundi Green Bds I C & $-1,09$ & $-1,14$ & 3,32 \\
\hline Amundi Imp Gr Bds I C & $-0,95$ & $-0,69$ & 3,32 \\
\hline AXAWF Global I Dis EUR & $-1,50$ & $-1,27$ & 2,53 \\
\hline BfS Nachhaltigkeitsfonds & $-1,31$ & $-2,21$ & 2,21 \\
\hline Calvert I & $-1,85$ & $-0,81$ & 3,43 \\
\hline JSS Glb P EUR acc & $-2,06$ & $-1,99$ & 3,33 \\
\hline Mirova Global N & $-0,82$ & $-0,65$ & 2,48 \\
\hline NN (L) I Cap EUR & 0,04 & 0,24 & 3,16 \\
\hline Raiffeisen- I T & $-1,80$ & $-1,02$ & 3,00 \\
\hline SEB D EUR & $-2,50$ & $-3,87$ & $-0,68$ \\
\hline MSCI All Country Index & 2,78 & $-0,56$ & 0,02 \\
\hline S\&P Global Dev Agg Bond Index & 2,01 & $-1,31$ & 2,69 \\
\hline S\&P Green Bond Index & 3,20 & $-1,43$ & 2,06 \\
\hline
\end{tabular}

A Sharpe-ráta egy másik továbbfejlesztett mutatója az $\mathrm{M}^{2}$-mutató, amely kiküszöböli a ráta tényleges, számszaki összehasonlíthatóságának hiányát (3. táblázat). A Sharpe-ráta csak rangsorolja az alapokat a kockázattal korrigált teljesítményük szerint, de az $\mathrm{M}^{2}$-mutató a portfólió kockázatát a piaci kockázatához igazítja, és megadja az így kialakított portfólió elméleti hozamának és a benchmark hozamának a különbségét. Megmutatja, mennyivel teljesített jobban vagy rosszabbul az adott alap a piacnál. Jelen tanulmányban a zöld prémium mértékére következtetünk a mutató alakulásából.

Megjegyezzük, hogy a negatív Sharpe-rátájú alapok itt nem értelmezhetők, és torzítják az eredményeket, nélkülük (JSS Glb P, BfS Nachhaltigkeitsfonds, és SEB D EUR) a zöld prémium $+0,2$ és $-1,75$ bázispont között változik (4. táblázat). A részvényindexhez viszonyítva tehát nincs zöld prémium, átlagosan 0,2 százalékkal magasabb hozamot produkáltak a zöldkötvény-alapok. Számításunk szerint a kötvény- és a zöldkötvény-indexnél a zöldkötvény-alapok átlagosan mintegy 1,58-1,75 százalékkal maradtak alul, ami azt jelenti, hogy a zöldkötvény-alapok átlagosan 1,6 bázispont zöld prémiumot fizetnek, ami megfelel a szakirodalmakban (MacAskill et al. 2021; Harrison 2019; Gianfrate - Peri 2019) mért értékeknek. 


\begin{tabular}{|c|c|c|c|}
\hline \multicolumn{4}{|c|}{$\begin{array}{l}\text { 4. táblázat } \\
\text { Az } \mathrm{M}^{2} \text {-mutatók alakulása mindhárom piaci (benchmark) indexhez viszonyítva }\end{array}$} \\
\hline & $\begin{array}{c}\mathrm{M}^{2} \text {-mutató (\%) } \\
\text { (részvényindex) }\end{array}$ & $\begin{array}{l}\mathrm{M}^{2} \text {-mutató (\%) } \\
\text { (kötvényindex) }\end{array}$ & $\begin{array}{c}\mathrm{M}^{2} \text {-mutató (\%) } \\
\text { (zöldkötvény-index) }\end{array}$ \\
\hline NN (L) & 5,49 & 0,38 & 0,11 \\
\hline S\&P Green Bond Index & 5,17 & 0,26 & - \\
\hline S\&P Global Bond Index & 4,47 & - & $-0,25$ \\
\hline Amundi Imp & 2,29 & $-0,80$ & $-1,02$ \\
\hline Amundi Green & 0,02 & $-1,64$ & $-1,82$ \\
\hline MSCI All Country Index & - & $-1,65$ & $-1,82$ \\
\hline Calvert I & $-0,10$ & $-1,69$ & $-1,86$ \\
\hline Mirova Global N & $-0,76$ & $-1,93$ & $-2,09$ \\
\hline Allianz W EUR & $-1,36$ & $-2,15$ & $-2,30$ \\
\hline Raiffeisen- I T & $-1,42$ & $-2,17$ & $-2,33$ \\
\hline AXAWF Global & $-2,55$ & $-2,59$ & $-2,72$ \\
\hline Átlagos zöld prémium & 0,20 & $-1,58$ & $-1,75$ \\
\hline
\end{tabular}

A Sharpe-ráta és a Sortino-ráta értékei csak az átlaghozamtól, a kockázatmentes hozamtól és a teljes vagy alsóági kockázattól függnek. A mutatókat nem befolyásolta a benchmark-index megválasztása, mindegy, hogy a hagyományos vagy zöld indexekhez mértük a teljesítményüket. $\mathrm{Az} \mathrm{M}^{2}$-mutató számolásában azonban a benchmark-indexet is használjuk, ezért mind a három index esetén feltüntettük az eredményeket, noha a későbbi számításunkból kiderül, valójában csak az egyik benchmark-index korrelál a zöldkötvény-alapok hozamával.

Csak a kockázattal korrigált mutatók figyelembevétele nem elegendő annak meghatározásához, hogy az alapok relatívan hogyan teljesítettek, ezért a következőkben a CAPM-modellen alapuló, egyváltozós indexmodellel számított eredményeket mutatjuk be. Előtte a választott benchmarkokra szükséges tennünk kitekintőt. Az alfa és a béta értékei, melyek a portfóliómenedzser kiválasztási és alapkezelő képességét, illetve az alapok piaccal való együttmozgását mérik, érzékenyek a választott benchmarkokra. Ezért felmerül a kérdés, melyik benchmarkot válasszuk.

A zöldkötvény-alapok és a globális részvénypiac között kis mértékű negatív korrelációt találtunk, mely -0,2 és 0 között mozog, így t-teszttel megerősítettük, hogy a két hozam értéke egymástól független. Az alapok és kötvényindexek között azonban már erősebb, pozitív irányú szignifikáns korreláció mérhető. Meglepő, de azt kaptuk, hogy a globális kötvényindex jobban korrelál a zöldkötvény-portfóliókkal, mint a zöld index. Ennek az lehet az oka, hogy míg az előbbi tartalmazhat zöldértékpapírokat is, de az utóbbi kizárja a hagyományos kötvényeket, így összetétele kevésbé hasonlít az alapokéhoz. Bauer et al. (2005) az etikus befektetési alapok elemzéséből szintén 
arra jutott, hogy az etikus indexek magyarázó ereje igen gyenge. A korrelációvizsgálatban kapott eredményekből kiindulva a globális kötvényindexhez viszonyítjuk az alapok hozamprémiumát, miután a korrelációs számítás szerint az $\mathrm{MSCl}$ World index kevésbé magyarázza azok mértékét.

Az 5. táblázat az S\&P Global Bond kötvényindexszel futtatott regressziós egyenlet eredményeit tartalmazza, ahol a függő változó az index hozamprémiuma, a független változó pedig az alapok kockázatmentes hozam feletti prémiumai. A Jensen-alfa alapvetően a CAPM-modell szerinti, várható hozam feletti többlethozamot adja meg, de annak már említett gyakorlati nehézségei miatt az indexmodellt alkalmazzuk a hozamprémiumok mérésére.

5. táblázat
\begin{tabular}{l|c|c|c} 
Az egyváltozós indexmodell paraméterei a kötvényindex-benchmarkkal \\
\multicolumn{1}{c}{ Zöldkötvény-alapok } & Alfa (\%) & Béta & $\mathbf{R}^{2}$ \\
\hline Allianz W EUR & 0,001 & $0,16^{*}$ & 0,06 \\
\hline Amundi Green Bds I C & 0,0026 & $0,37^{*}$ & 0,28 \\
\hline Amundi Imp Gr Bds I C & 0,0045 & $0,38^{*}$ & 0,33 \\
\hline AXAWF Global I Dis EUR & 0,0003 & $0,35^{*}$ & 0,25 \\
\hline BfS Nachhaltigkeitsfonds & $-0,0011$ & $0,19^{*}$ & 0,13 \\
\hline Calvert I & 0,0016 & $0,40^{*}$ & 0,42 \\
\hline JSS Glb P EUR & $-0,0022$ & $0,34^{*}$ & 0,28 \\
\hline Mirova Global N & 0,0022 & $0,40^{*}$ & 0,20 \\
\hline NN (L) I Cap EUR & 0,0099 & $0,39^{*}$ & 0,21 \\
\hline Raiffeisen- I T & 0,0058 & $0,06^{*}$ & 0,01 \\
\hline SEB D EUR & $-0,0068^{*}$ & $0,37^{*}$ & 0,13 \\
\hline Megjegyzés: * $<0,05$ & & & \\
\hline
\end{tabular}

A zöldkötvény-alapok teljesítményéről elmondható, hogy a 11 aktívan kezelt alap közül a nyolc pozitív alfájú alap felülteljesítette a piacot reprezentáló, globális kötvényindex-benchmarkot. A Jensen-alfával kapott kockázattal kiigazított, abnormális hozamok eredményei összhangban állnak korábbi számításainkkal, miszerint a BfS Nachhaltigkeitsfonds, a JSS GIb P EUR és a SEB D EUR alapok negatív hozamot, negatív Sharpe-rátát és szintén negatív Sortino-rátát produkáltak. A p-értékek 5 százalékos szignifikanciaszinten mért vizsgálatakor azonban csak a SEB-alap esetében vethetjük el a nullhipotézist, tehát a kötvényindextől szignifikánsan csak az egyik, legrosszabbul teljesítő alap teljesítménye különbözik, azonban a determinációs együttható értékének alacsony volta miatt a zöld prémiumra vonatkozóan messzemenő következtetések nem vonhatók le.

Elemzésünkben a szignifikáns bétákból látható, hogy a benchmark-index jól magyarázza az alapok teljesítményét. $A$ béták t-próbájával egy eszköz piaci érzékenységét 
magyarázzuk, a béta a benchmark-index hozamának egységnyi változására az adott eszköz hozamában bekövetkezett változást adja meg. A béták átlaga 0,21 , tehát kis mértékben mozognak együtt a piaccal, és kevésbé kockázatos eszközöknek minősülnek. A Calvert I alap bétája a legmagasabb, 0,42, és a determinációs együttható is itt mutatja a legnagyobb értéket, vagyis a Calvert I alap hozamprémiumának a varianciáját a globális kötvényindex 42 százalékban magyarázza.

Összességében az aktív alapkezelésnek tehát nem volt hatása a zöldkötvény-alapok hozamainak alakulására, az alapkezelő tevékenysége sikertelen volt, mert képességével nem tudta megverni a piacot. Eredményünk alátámasztja Fama és French (2020) eredményeit az aktívan kezelt amerikai részvényalapokról, amelyek hosszú távon a piacot alulteljesítették még költségkorrekció után is, sőt, alapvetően negatív alfákat kaptak az aktívan kezelt alapokra.

\section{6. Összefoglalás}

A tőkepiacokon zöld forradalom zajlik. A klímacélok megvalósulását szolgáló, fenntartható papírok népszerű befektetési lehetőségnek tűnnek, azonban meglepő módon elterjedésük kulcsa nem feltétlenül rejlett a magasabb hozamban. A zöldkötvények empirikus irodalmából bemutattuk, hogy a befektetők hajlandók lemondani a hozam egy részéről a kibocsátók javára, és részt venni a klímafinanszírozásban, zöld prémium fizetésével támogatva a fenntartható célok elérését. A zöld prémium egy másik, hasonló tulajdonsággal bíró konvencionális eszközhöz mért negatív hozam, azaz a befektető részéről egyfajta hozamáldozatnak tekinthető, amelyből a kibocsátó a termék zöld minősítésének érdekében felmerült költségeit finanszírozza. Kutatásunkból az is kiderül azonban, hogy a befektetők „zöldítő” eszközallokálása nem kell, hogy veszteséget realizáljon, számukra akár már középtávon is jövedelmező stratégia lehet.

Két hipotézist fogalmaztunk meg. Az első hipotézist elfogadtuk, hiszen a hozamok alakulásából és a kockázattal korrigált mutatókból is látható volt a zöldkötvény-alapok benchmarkokhoz viszonyított alulteljesítése. Az $\mathrm{M}^{2}$-mutató átlagos értékéből két benchmark esetén is bebizonyosodott a zöld prémium létezése, és a részvényindexhez viszonyítva csak minimálisan teljesítettek jobban a zöldkötvények. A CAPM-alapú regressziós modellből azonban az alacsony magyarázó erő és az inszignifikáns eredmények miatt a zöld prémiumra nem tudtunk érvényes következtetéseket levonni. A másik hipotézisünket szintén elfogadtuk, mert egyetlenegy zöldkötvény-alap, az NN (L) alap mindvégig kiemelkedő teljesítményt mutatott, tehát elképzelhető zöld prémium nélküli, jövedelmező zöldkötvény-portfólióba fektetni.

Kutatásunk azt az összefüggést támasztja alá, hogy a befektetők választása a zöldkötvényekbe való invesztálással kezdetben ugyan „csak” reputációs értéket képviselt, de idővel, az adatainkból kirajzolódó trend folytatásával, a zöld prémium eltűnik, és 
a zöldkötvényektől jobb teljesítmény, magasabb hozam is várható. A teljes időszakot vizsgálva, a 11 zöldkötvényből álló portfólió alapjainak nagy részénél igazoltuk a zöld prémium meglétét, az évek előre haladtával azonban a zöld prémium kevésbé jelent meg, és kisebb mértékben. Egy másik, irodalmakban elterjedt nézetet sikerült így azonosítanunk, mégpedig a zöld prémium piac általi beárazódását. A Sortino-ráták évenkénti vizsgálatából kiderült, hogy a zöldkötvények egyre jobban teljesítenek, és némelyik a benchmark-indexek felülteljesítésére is képes.

Megállapításainkkal kiemeljük a környezeti preferenciák megerősítésének szerepét és jelentőségét a kötvénypiaci szereplők körében. A környezetbarát befektetői preferenciák tőkésítése fontos katalizátora lehet az éghajlatváltozás „veszélyes” hatásainak elkerülése és mérséklése érdekében. Annak ellenére, hogy a zöldkötvény-alapok nem teljesítettek jól a teljes mintában, láthattuk, hogy idővel eltűnhet a zöld prémium, és jövedelmező befektetésekké is válhatnak, de úgy véljük, csak akkor, ha a zöld(kötvény)- alapok körüli szabályozási kérdések tisztázódnak.

\section{Felhasznált irodalom}

Baker, M. - Bergstresser, D. - Serafeim, G. - Wurgler, J. (2018): Financing the Response to Climate Change: The Pricing and Ownership of U.S. Green Bonds. SSRN Electronic Journal. http://doi.org/10.2139/ssrn.3275327

Baranyai Eszter - Banai Ádám (2020): Do climate change projections appear in mortgage characteristics? 11th Annual Financial Market Liquidity Conference, Hungary, 26-27 November.

Bauer, R. - Koedijk, C.G. - Otten, R. (2005): International evidence on ethical mutual fund performance and investment style. Journal of Banking and Finance, 29(7): 1751-1767. https://doi.org/10.1016/j.jbankfin.2004.06.035

Bodie, Z. - Kane, A. - Marcus, J.A. (2005): Befektetések. Aula Kiadó.

Boros Eszter (2020): A klímaváltozás kockázatai és a hitelintézeti stressztesztek. Hitelintézeti Szemle, 19(4): 107-131. http://doi.org/10.25201/HSZ.19.4.107131

CBI (2017): Green bonds policy: Highlights from 2016. Technical report, Climate Bonds Initiative. https://www.climatebonds.net/files/files/2016\%20GB\%20Market\%20Roundup. pdf. Letöltés ideje: 2019. május 5.

CBI (2020): 2019 Green Bond Market Summary. Technical report, Climate Bonds Initiative. https://www.climatebonds.net/files/reports/2019_annual_highlights-final.pdf. Letöltés ideje: 2019. május 5. 
Chen, Y.S. - Chang, C.H. (2012): Enhance green purchase intentions: The roles of green perceived value, green perceived risk, and green trust. Management Decision, 50(3): 502-520. https://doi.org/10.1108/00251741211216250

Climent, F. - Soriano, P. (2011): Green and Good? The Investment Performance of US Environmental Mutual Funds. Journal of Business Ethics, 103: 275-287. https://doi. org/10.1007/s10551-011-0865-2

Deschryver, P. - de Mariz, F. (2020): What Future for the Green Bond Market? How Can Policymakers, Companies, and Investors Unlock the Potential of the Green Bond Market? Journal of Risk Financial Management, 13(3): 61. https://doi.org/10.3390/jrfm13030061

Ehlers, T. - Packer, F. (2017): Green Bond Finance and Certification. BIS Quarterly Review, September: 89-104. https://www.bis.org/publ/qtrpdf/r_qt1709h.htm. Letöltés ideje: 2019. május 5.

Fama, E.F. - French, K.R. (2010): Luck Versus Skill in the Cross Selection of Mutual Fund Returns. The Journal of Finance, 65(5): 1915-1947. https://doi.org/10.1111/j.15406261.2010.01598.x

Filkova, M. - Boulle, B. - Frandon-Martinez, C. - Giorgi, A. - Giuliani, D. - Meng, A. - Rado, G. (2018): Bonds and Climate Change: The State of the Market 2018. https://www. climatebonds.net/files/reports/cbi_sotm_2018_final_01k-web.pdf. Letöltés ideje: 2019. május 5.

Fogarassy, Cs. - Neubauer, É. - Mansur, H. - Tangl, A. - Oláh, J. - Popp, J. (2018): The main transition management issues and the effects of environmental accounting on financial performance - with focus on cement industry. Administratie si Management Public (31), pp. 52-66. https://www.ceeol.com/search/article-detail?id=718218. Letöltés ideje: 2021. február 8.

Forsbacka, K. - Vulturius, G. (2019): A Legal Analysis of Terms and Conditions for Green Bonds. Europarättslig Tidskrift 3: 379-442. https://www.stockholmsustainablefinance. com/wp-content/uploads/2018/06/Forsbacka_Vulturius_2019.pdf. Letöltés ideje: 2021. június 5 .

Gianfrate, G. - Peri, M. (2019): The green advantage: Exploring the convenience of issuing green bonds. Journal of Cleaner Production, 219: 127-135. https://doi.org/10.1016/j. jclepro.2019.02.022

Gyura Gábor (2020): Az addicionalitás vizsgálata a zöld kötvények kapcsán. PhD-értekezés, Pécsi Tudományegyetem. https://pea.lib.pte.hu/bitstream/handle/pea/23690/gyuragabor-phd-2020.pdf?sequence=1\&isAllowed=y. Letöltés ideje: 2021 . február 8. 
Hachenberg, G. - Schiereck, D. (2018): Are green bonds priced differently from conventional bonds? Journal of Asset Management, 19(6): 383-423. https://doi.org/10.1057/s41260018-0088-5

Harrison, S. (2019): Green Bond pricing in the primary market: January - June 2019. https:// www.climatebonds.net/files/reports/cbi_gb_pricing_h1_2019_final.pdf. Letöltés ideje: 2020. január 5 .

Hyun, S. - Park, D. - Tian, S. (2018): The price of going green: The Role of Greenness in Green Bond Markets. http://www.iksa.or.kr/resource/global/hak/2018-1-1.pdf. Letöltés ideje: 2020. január 5.

IBA (2021): Green Bond Principles and the EU framework for green finance. International Bar Association. https://www.ibanet.org/article/f43b78f6-59d7-4b29-a332-e10ccc9ff0be\#_ ftnref2. Letöltés ideje: 2021. április 25.

Ibikunle, G. - Steffen, T. (2017): European Green Mutual Fund Performance: A Comparative Analysis with their Conventional and Black Peers. Journal of Business Ethics, 145(2): 337355. https://doi.org/10.1007/s10551-015-2850-7

ICMA (2019): Green Bond Principles Voluntary Process Guidelines for Issuing Green Bonds. International Capital Market Association. https://www.icmagroup.org/assets/documents/ Regulatory/Green-Bonds/June-2018/Green-Bond-Principles---June-2018- 140618-WEB. pdf. Letöltés ideje: 2020. szeptember 5.

Jókuthy Laura (2020): Zöld kötvények. Befektetés a jövő generációjának. Szakmai cikk, Magyar Nemzeti Bank. https://www.mnb.hu/letoltes/jokuthy-laura-zold-kotvenyek-befektetes-ajovo-generaciojanak.pdf. Letöltés ideje 2021. február 5.

Karpf, A. - Mandel, A. (2018): The changing value of the 'green' label on the US municipal bond market. Nature Climate Change, 8(2): 161-165. https://doi.org/10.1038/s41558017-0062-0

Kidd, D. (2015): Indexes Sprout Up as Green Bonds Take Root. Investment Risk and Performance. 2015(1). https://deborahkidd.com/wp-content/uploads/Indexes-SproutUp-as-Green-Bonds-Take-Root-1.pdf. Letöltés ideje: 2019. február 2.

Kolozsi Péter Pál (2019): Piaci összeomlással fenyeget a klímaváltozás? Economania. https:// economaniablog.hu/2019/12/17/piaci-osszeomlassal-fenyeget-a-klimavaltozas/. Letöltés ideje: 2021. április 25.

Lovas Anita - Berlinger Edina - Dömötör Barbara - Keresztúri Judit Lilla - Ölvedi Tímea - Petróczy Dóra Gréta - Pollák Zoltán (2019): Pénzügyi számítások - Bevezetés a pénzügyi termékek értékelésébe. http://unipub.lib.uni-corvinus.hu/4465/1/ PenzugyiSzamitasokKonyv_201912.pdf. Letöltés ideje: 2020. február 5. 
MacAskill, S. - Roca, E. - Liu, B. - Stewart, R.A. - Sahin, O. (2021): Is there a green premium in the green bond market? Systematic literature review revealing premium determinants. Journal of Cleaner Production, 280(2): 124491. https://doi.org/10.1016/j. jclepro.2020.124491

MNB (2019): Zöld pénzügyek Magyarországon. Konzultációs dokumentum, Magyar Nemzeti Bank. https://www.mnb.hu/letoltes/zold-penzugyek-konzultacios-dokumentum.pdf. Letöltés ideje: 2020.01.05.

Mihálovits Zsolt - Tapaszti Attila. (2018): Zöldkötvény, a fenntartható fejlődést támogató pénzügyi instrumentum. Pénzügyi Szemle, 2018(3): 312-327.

Nanayakkara, M. - Colombage, S. (2019): Do investors in Green Bond market pay a premium? Global evidence. Applied Economics, (51)40: 4425-4437. https://doi.org/10.1080/0003 6846.2019.1591611

Németh-Durkó Emilia (2019): Környezet és pénzügyek. Múhelytanulmány, Budapesti Corvinus Egyetem Befektetések és Vállalati Pénzügy Tanszék, Budapest. http://unipub.lib.unicorvinus.hu/4294/. Letöltés ideje: 2019. november 1.

OECD (2017): Investing in Climate, Investing in Growth. OECD Publishing, Paris. http://doi. org/10.1787/9789264273528-en

Partridge, C. - Medda, F.R. (2020): The evolution of pricing performance of green municipal bonds. Journal of Sustainable Finance and Investments, 10(1): 44-64. https://doi.org/10 $.1080 / 20430795.2019 .1661187$

Pham, L. (2016): Is it risky to go green? A volatility analysis of the green bond market. Journal of Sustainable Finance \& Investment, 6(4): 1-29. http://doi.org/10.1080/20430795.201 6.1237244

Rácz Dávid Andor (2019): Abszolút hozamú befektetési alapok teljesítményének értékelése - a teljesítménymanipulálás kimutatása. Közgazdasági Szemle, 66(7-8): 824-846. https:// doi.org/10.18414/KSZ.2019.7-8.824

Reichelt, H. (2010). The euromoney environmental finance handbook - Green bonds: a model to mobilise private capital to fund climate change mitigation and adaptation projects. https://documents1.worldbank.org/curated/en/680921507013408005/pdf/120168-BRIPUBLIC-euromoney-handbook-2010-green-bonds.pdf. Letöltés ideje: 2019. május 2.

Sági Judit (2020): Zöldkötvények kibocsátásának egyes kérdései, a környezeti célokkal összefüggésben. Polgári Szemle, 16(4-6): 270-278. https://doi.org/10.24307/ psz.2020.1019

Stempler Balázs (2021): ESG-befektetés: Az ESG-értékelések alkalmazása smart beta stratégiában. Hitelintézeti Szemle, 20(2): 91-116. http://doi.org/10.25201/HSZ.20.2.91116 
Sartzetakis, E.S. (2020): Green bonds as an instrument to Finance low carbon transition. Economic Change and Restructuring, 54: 755-779. https://doi.org/10.1007/s10644-02009266-9

Shislov, I. - Morel, R. - Cochran, I. (2016): Beyond transparency: unlocking the full potential of green bonds. Institute for Climate Economics. https://www.i4ce.org/wp-core/wp-content/ uploads/2016/06/I4CE_Green_Bonds-1.pdf. Letöltés ideje: 2019. február 2.

Timár Barnabás (2021): Hogyan árazza a piac a felelös és fenntartható befektetéseket? Hitelintézeti Szemle, 20(2): 117-147. http://doi.org/10.25201/HSZ.20.2.117147

Taghizadeh-Hesary, F. - Yoshino, N. - Phoumin, H. (2021): Analyzing the Characteristics of Green Bond Markets to Facilitate Green Finance in the Post-COVID-19 World. Sustainability, 13(10): 5719. https://doi.org/10.3390/su13105719

Tang, D.Y. - Zhang, Y. (2018): Do shareholders benefit from green bonds? Journal of Corporate Finance, 61(C). https://doi.org/10.1016/j.jcorpfin.2018.12.001

Tuhkanen, H. - Vulturius, G. (2020): Are green bonds funding the transition? Investigating the link between companies' climate targets and green debt financing. Journal of Sustainable Finance \& Investment. https://doi.org/10.1080/20430795.2020.1857634

Zerbib, O.D. (2019): The effect of pro-environmental preferences on bond prices: Evidence from green bonds. Journal of Banking \& Finance, 98(January): 39-60. https://doi. org/10.1016/j.jbankfin.2018.10.012 